\title{
Design of Smart Garden Based On The Internet of Things (IoT)
}

\author{
Atmiasri \\ Department of Electrical Engineering \\ University of PGRI Adi Buana Surabaya \\ Atmi.asri@unipasby.ac.id
}

\author{
Andika Tri Wiyono \\ Department of Electrical Engineering \\ University of PGRI Adi Buana Surabaya \\ andikatriwiyono12@gmail.com
}

\begin{abstract}
Currently, the control of cultivated plants is still manual, where farmers watering and checking soil moisture on the planting object. However, we cannot avoid technological progress in this life because technological progress will run following scientific advances. Therefore, every innovation is created to provide positive benefits for life. The ideal chili cultivation planning requires information about climatic conditions that play a significantrole in chili cultivation is rainfall. Plant growth will be incredible if there is sufficient water supply; humidity for chili plants ranges from $\mathbf{6 0 - 8 0 \%}$. Therefore, chili cultivation planning must pay attention to rainfall because related to water availability. Smart Garden prototype design is a solution for taking appropriate actions during extreme weather and reducing human error. $A$ prototype Smart Garden-based Internet of Things (IoT) using the Blynk app as User Interface (GUI) in the monitoring system and using the Soil Moisture sensor as input for soil moisture conditions, where the results of the process are sent via Wemos D1 mini-module to the Blynk server to display the state of soil moisture and automatic watering.
\end{abstract}

Keywords-Blynk, IoT, Chilli Cultivation, Smart Garden.

\section{INTRODUCTION}

In everyday life, everyone has different habits in filling their free time and life. It can be filled with hobbies that make the heart happy, namely hobbies. Hobby is an activity that is often done by humans and makes humans who do it can be entertained. Some examples of hobbies that humans do are fishing, futsal, basketball, raising livestock.

According to Efendi and Yoyon (2018), stating that the Internet of Things(IoT) can be used in buildings to control various kinds of electronic equipment such as lights and room temperature that can be operated or turned on remotely via computer or smartphone networks, it is unavoidable that progress Today's increasingly rapid technology must be used, studied and applied in everyday life

The way the Internet of Things (IoT) works, according to Safrianti Ery andAfiantoni (2020) is by utilizing a programming argument where each argument command can produce an interaction between machines that are connected automatically without human intervention and within as far as possible. The internet which is the link between the two machine interactions The IoT concept isactually quite simple with the way it works referring to 3 main elements in the IoT architecture, namely: Physical Goods equipped with IoT modules, Connection Devices to the Internet such as Modems and Speedy Wireless Routers like in your home, and Cloud Data Center where to store applications and database.

According to Kurnia Deni (2016), Smart Garden is a prototype of an automatic plant care or monitoring system, where the monitoring system is designed through the Blynk IoT application. The design of this prototype aims to help control the cayenne pepper plant care system at the individual level (personaluser).

Humidity for cayenne pepper plants ranges from $60-80 \%$. High humidity will make plants susceptible to disease. Conditions of high rainfall can cause cold temperatures to increase dramatically so it is necessary to set a more tenuous 
BEST

Journal of Applied Electrical \& Science Technology - University of PGRI Adi Buana Surabaya

p-ISSN 2715-2871

e-ISSN 2714-5247

distance between plants (Prajnanta, 2011; Imtiyaz, et al, 2017)

Plant cultivation is currently in a problem of limited time and opportunity to carry out maintenance, which requires an idea to be able to have your own chili garden easily and practically. Then the Internet of Things (IoT) is needed to help human work with the help of technology. Internet of Things is a scenario that utilizes internet and computer network connections that are developed for objects, sensors, and devices that are used daily (Kusuma, et al, 2019).

According to Sakaki et al (2018), states that the soil moisture sensor depends a lot on the sample which can be defined as the volume of soil around thesensor. Where changes in water content affect sensor readings. Multiple and continuous sampling to determine accurate volumetric moisture content values. Detailed quantification of the sampling volume including the effect of the electromagnetic energy density distribution decreasing with distance from the branch surface can be performed numerically.

The problems faced by plant cultivation farmers today are the unavailability of appropriate information and limited time for watering and fertilizing plants. Giving water to plants automatically which is controlled by an Arduino microcontroller based on data from measurements or detection of temperature and humidity around the plant by the DHT11 sensor is a solution to ease the work and increase farmer productivity (Jamal, 2017).

According to Kusuma, et al (2019), states that the Soil Moisture Sensor Module is a module that functions to detect soil moisture levels and can also be used to determine whether there is water content in the soil around the sensor. This sensor is used to test soil moisture, when the soil is experiencing a lack of water, the output of the module is at a high level, or the output is at a low level.

\section{METHODS}

\section{A. Product Design of Smart Garden}

$\begin{array}{ll}\text { Height } & : 40 \mathrm{~cm} \\ \text { Area } & : 40 \mathrm{~cm} \\ \text { Length } & : 40 \mathrm{~cm}\end{array}$

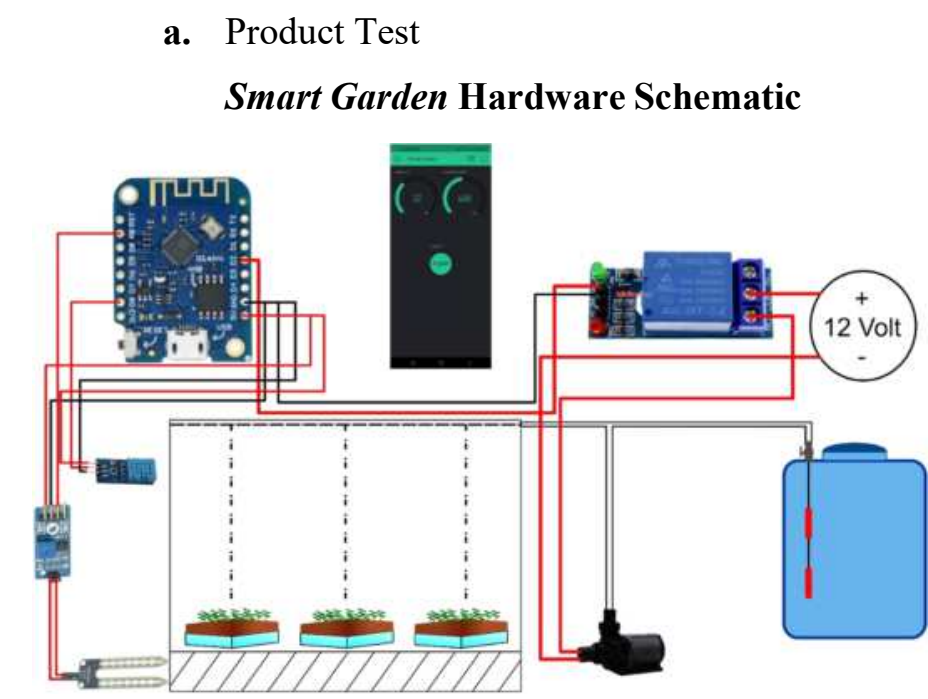

b. Temperature monitoring process flow chart

The monitoring process is carried out by reading the DHT11 sensor output and processed using the esp 8266 module. The system takes the last condition of the sensor output reading and checks the connection on the esp8266 module to display the nominal temperature on the Blynk application.

c. Flowchart of soil moisture monitoring process

The process of monitoring soil moisture is carried out by reading the output ofthe Soil Moisture sensor and processed using the esp8266 module. The systemwill read the last condition read by the sensor, then the esp8266 module will check the connection and display the nominal temperature on the Blynk application. 
d. Watering process flow chart

The watering process is carried out by paying attention to the temperature and humidity of the soil. On the Blynk application screen there is a nominal displayof temperature, soil moisture, and a watering pump switch. If the switch is positioned "ON" the esp8266 module will send a signal to the relay, the relay is connected to the watering pump and the pump will turn on.

\section{RESULTS AND DISCUSSION}

Product result and evaluation

a. Hardware and software testing

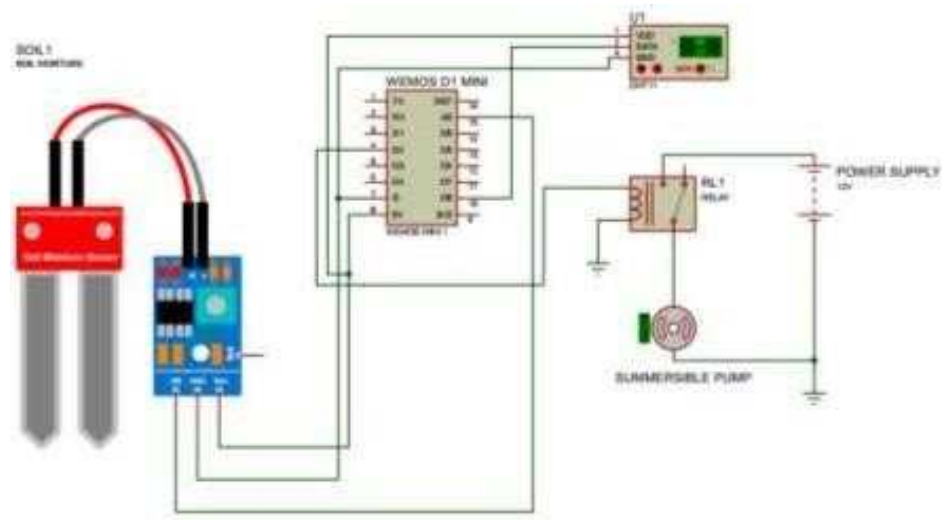

b. Wemos D1 mini module voltage test

\begin{tabular}{|c|l|l|}
\hline No & Component Name & Amount \\
\hline $\mathbf{1}$ & Wemos D1 Mini & $1 \mathrm{pcs}$ \\
\hline $\mathbf{2}$ & USB Cable & $1 \mathrm{pcs}$ \\
\hline $\mathbf{3}$ & Breadboard & $1 \mathrm{pcs}$ \\
\hline $\mathbf{4}$ & Led lamp 5mm & $1 \mathrm{pcs}$ \\
\hline $\mathbf{5}$ & Jumper Cable & Enough \\
\hline
\end{tabular}

According to Abidin Z, et al (2019) stating that Wemos is one of the board modules that can function with Arduino, especially for projects that carry the IOT concept. Wemos can runstandalone without the need to be connected to a microcontroller,in contrast to other wifi modules that still require a microcontrolleras the controller or the brain of the circuit, wemos can run standalone because it already has a CPU that can program via serial portor via OTA and transfer programs wirelessly.

Step of method:

- Turn on the wemos D1 mini module board by connecting itvia USB cable with the computer.

- Start-up for the introduction of the wemos board, throughthe tools $>$ board >wemos D1 mini.

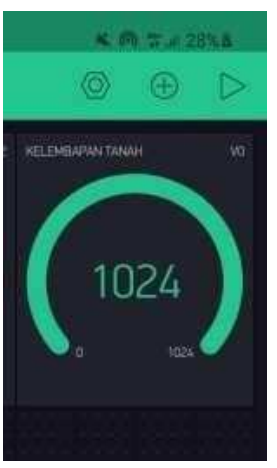

In dry

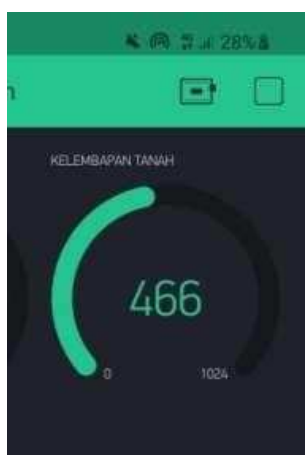

In wet

- Selecting serial communication wemos D1 mini, via tools

- >serial port >set "COM" after connecting to wemos D1mini module

c. Soil moisture sensor testing 
According to Noviansyah $\mathrm{M}$ and Saiyar Hafdiarsya (2019), this relay module can also be used as a switch to run various electronic equipment. For example, electric lamps, electric motors, and various other electronic equipment. Control of the $\mathrm{ON}$ or OFF switch (relay), is completely determined by the sensor output value, which after processing the Microcontroller will generate a command to the relay to perform theON or OFF function.

d. Testing DHT 11

Sensor test results DHT 11

\begin{tabular}{|c|c|c|c|}
\hline No & Time & $\begin{array}{c}\text { Sensor } \\
\text { DHT 11 }\end{array}$ & $\begin{array}{c}\text { Thermo } \\
\text { meter }\end{array}$ \\
\hline 1 & Morning & $27^{\circ} \mathrm{C}$ & $27,3^{\circ} \mathrm{C}$ \\
\hline 2 & Afternoon & $32,3^{\circ} \mathrm{C}$ & $32,3^{\circ} \mathrm{C}$ \\
\hline 3 & Night & $26,8^{\circ} \mathrm{C}$ & $27^{\circ} \mathrm{C}$ \\
\hline
\end{tabular}

According to Juliasari Noni, et al (2016), the DFRobot DHT11 sensor has a calibrated temperature and humidity setting and a digital signal output. With good digital signal detection techniques at temperature and humidity, this sensor is reliable and has long-termstability

e. Testing relay On

\section{Sensor value measurement results}

\begin{tabular}{|c|c|}
\hline Humidity & $\begin{array}{c}\text { Value of Soil } \\
\text { Moisture }\end{array}$ \\
\hline $0 \%$ & 1024 \\
\hline $100 \%$ & 322 \\
\hline
\end{tabular}

The sensor value that is read when the soil condition is saturated is 322 and when it is dry it is 1024 . The sensor value and humidity contained inthe table are used as the upper and lower limits in the interpolation of determining the value of moisture in normal soil.

\section{f. Smart Garden results in a dry state}

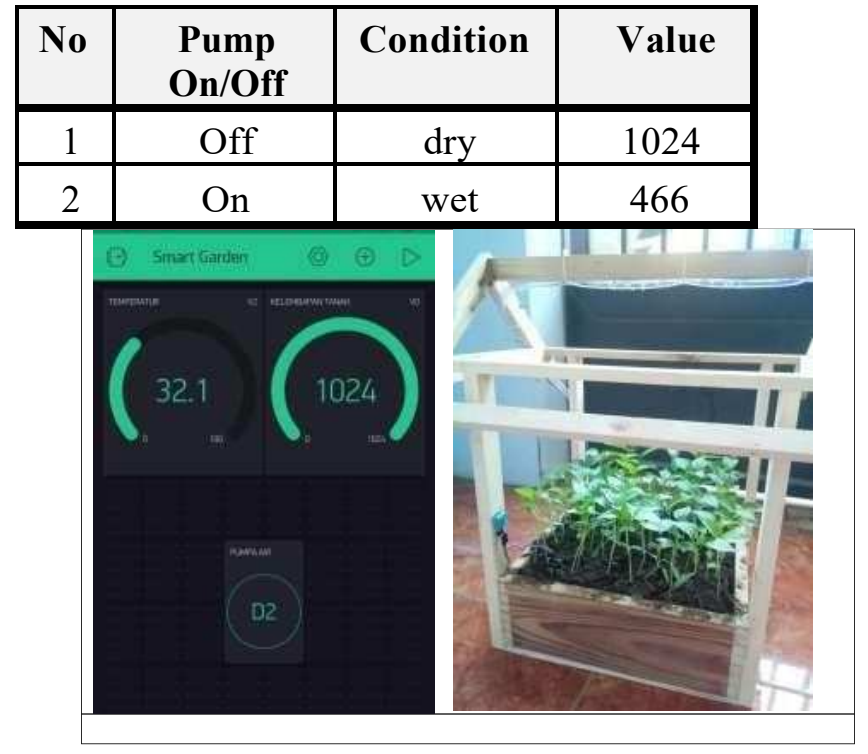

\section{CONCLUSIONS}

From the tests carried out, the results of this study can be concluded:

1) When the soil moisture sensor detects moisture in the soil and the DHT11 sensor when it detects the temperature the system is working properly it can send a data signal to the blynk application via the wemos D1 mini module. Soil moisture test obtained 1024 results when dry and 466 when wet, as well as in the ambient temperature test obtained $32^{\circ} \mathrm{C}$.

2) In the watering system using a pump and flowed by a pipe. The pump is run through the blynk application which has an on/off button which then sends a signal to the Wemos D1 mini output in the form of a 5 volt voltage which then turns on the relay, the relay contact is given a voltage of $12 \mathrm{v}$ according to the pump's needs. The watering system works well..

\section{REFERENCES}

[1] Abidin Z, Tijaniyah, Moh. Bachrudin, 2019. Rancang Bangun Pengoperasian Lampu Menggunakan Sinyal Analog Smartphone Berbasis Mikrokontroller. JEECOM, Vol. 1, No. 1

[2] Deni Kurnia. 2016. Rancang Bangun Prototipe Gardening Smart System (GGS) Untuk Perawatan Tanaman Anggrek Berbasis Web. Jurnal SIMETRIS, Vol. No. 1

[3] Efendi, Yoyon. 2018. Internet of Things (IoT) Sistem Pengendalian Lampu Menggunakan Raspberry PI 
Berbasis Mobile. Jurnal Ilmiah Ilmu Komputer,Vol.4, No.1

[4] Imtiyaz, Prasetio, dan Hidayat. 2017. Sistem Pendukung Keputusan Budidaya Tanaman Cabai Berdasarkan Prediksi Curah Hujan. Jurnal Pengembangan Teknologi Informasi dan Ilmu Komputer. Vol.1, No.9

[5] Kusuma, Darlis, dan Novianti. 2019. "Implementasi Smart Garden Watering Pada Taman Asrama Universitas Telkom Menggunakan Modul Ethernet Pada Raspberry PI Berbasis IoT". Vol.5, No.3.

[6] Mukhtar, M. Nushron Ali, and Sagita Rochman. "Analisis Simulasi Proses Ironing Untuk Mengetahui Ketinggian Dinding Berdasarkan Variasi Reduksi Ketebalan Dinding." WAKTU: Jurnal Teknik UNIPA 15.2 (2017): 66-72.

[7] Supriadi, Susila, Sulistyono. 2018. Penetapan Kebutuhan Air Tanaman Cabai Merah (Capsicum annuum L.) dan Cabai Rawit (Capsicum frutescens L.)

[8] Sujiwa, Akbar, and Sagita Rochman. "Pengembangan Sistem Kontrol Serta Monitoring Suhu dan Volume Air Berbasis Web Pada Perangkat Desalinasi Air Laut." SNHRP (2019): 1-9.

[9] Rochman, Sagita, and Bagus Ilham Yunianto. "PROTOTYPE AUTOMATIC LIGHTS CONTROL SYSTEM IN THE MOSQUE AREA BASED ON ARDUINO NANO." BEST: Journal of Applied Electrical, Science, \& Technology 1.1 (2019): 32-35.

[10] Rochman, Sagita, and M. Nushron Ali Mukhtar. "CLASSIFICATION OF THE QUALITY OF HONEY USING THE SPECTROFOTOMETER AND MACHINE LEARNING SYSTEM BASED ON SINGLE BOARD COMPUTER." Tibuana 2.01 (2019): 45-49.

[11] Sujiwa, Akbar, Atmiasri Atmiasri, and Edi Purwanto. "SISTEM KONTROL EFISIENSI DAYA OTOMATIS PADA PERANGKAT PROTOTIPE DESALINASI DUAL OUTPUT BERTENAGA SEL
SURYA." WAKTU: Jurnal Teknik UNIPA 17.1 (2019): 26-31.

[12] Sujiwa, Akbar, and Endarko Endarko. "Wire-Mesh 16× 16 Capacitance Sensor for Analysis of Capacitance Distribution on Cylindrical Pipe." IPTEK Journal of Proceedings Series 1 (2018): 130-135. 